\title{
Morphological Classification of Fluvial Environments: An Investigation of the Continuum of Channel Types
}

\author{
G. L. Heritage, M. E. Charlton, ${ }^{1}$ and S. O'Regan ${ }^{2}$ \\ Institute of Environmental Systems, Department of Geography, University of Salford, Greater Manchester \\ M5 4WT, United Kingdom \\ (e-mail: G.L.Heritage@Salford.ac.uk)
}

\begin{abstract}
A B S T R A C T
Bedrock-controlled channel systems exhibit considerable morphological variation. Both bedrock-influenced and alluvial morphological units coexist to form a system of changing channel patterns in response to changes in the relative influence of the controlling process variables. This article investigates the morphological composition of the bedrockinfluenced Sabie River, Mpumalanga Province, South Africa, mapping $25 \mathrm{~km}$ of river channel at the scale of individual morphological units. Cluster and discriminant analyses define objective reach-scale "channel type" assemblages based on morphological unit composition. A number of robust clusters emerged that could be broadly classified into five channel types, namely, bedrock anastomosed, mixed anastomosed, pool-rapid, braided, and alluvial single-thread. The cluster analysis revealed that these channel types fit on a continuum from bedrock-dominated channels to fully alluvial systems. Each channel type could also be characterized by a certain set of "dominant" morphological units, which changed from bedrock-influenced at one end of the continuum (bedrock anastomosed, pool-rapid) to alluvial deposits at the other (braided, alluvial single-thread). An investigation of the role of controlling process variables in defining these channel types revealed a broad link between the degree of bedrock influence and the amount of available energy within the system as defined by indices such as the flow regime and water-surface slope variation. It is clear that the bedrock-dominated channel types are characterized by energy levels in excess of those accepted for alluvial systems, and an extended river classification is presented for the Sabie River that includes these bedrock channels. The mixed anastomosing channel type on the Sabie River is characterized by higher available energy levels than braided or alluvial single-thread reaches. As such, it appears to be a higher-energy example of an anabranched system, probably formed as a result of sediment accumulation on top of a high-energy bedrock anastomosed channel template.
\end{abstract}

\section{Introduction}

River channel classification and, in particular, morphological zonation have received considerable attention in the past decade (Church 1992; Rosgen 1994; van Niekerk et al. 1995; Newson et al. 1998). Differentiation has been made on a variety of grounds, including channel size and gradient, with step-pool channels characterizing upland watercourses and riffle-pool sequences in lowland alluvial channels.

Ashley et al. (1988) recognized continuum features within the Raritan River, New Jersey, related

\footnotetext{
Manuscript received February 15, 2000; accepted July 25, 2000.

${ }^{1}$ Department of Geography, University of Newcastle, Newcastle upon Tyne NE1 7RU, United Kingdom.

${ }^{2}$ Center for Water in the Environment, Department of Botany, University of the Witwatersrand, Johannesburg, South Africa.
}

to the degree of alluvial sediment deposited over bedrock. They argued for progressive alluviation within the river, which may fully cover the bedrock in some reaches with sediment leading to the channel, assuming a more alluvial nature. This article demonstrates a similar situation on the Sabie River in Mpumalanga Province, South Africa, but demonstrates that deposition appears to occur in such a way as to form associations of sedimentary units over bedrock that generates several distinct channel types that range from bedrock to fully alluvial.

Many river classification systems have been proposed; however, few are generic for a range of applications. Instead, these classifications use physical, chemical, and biological criteria on a variety of spatial scales. More recently, classification systems have been formulated using a hierarchical approach that links features on a variety of scales, 


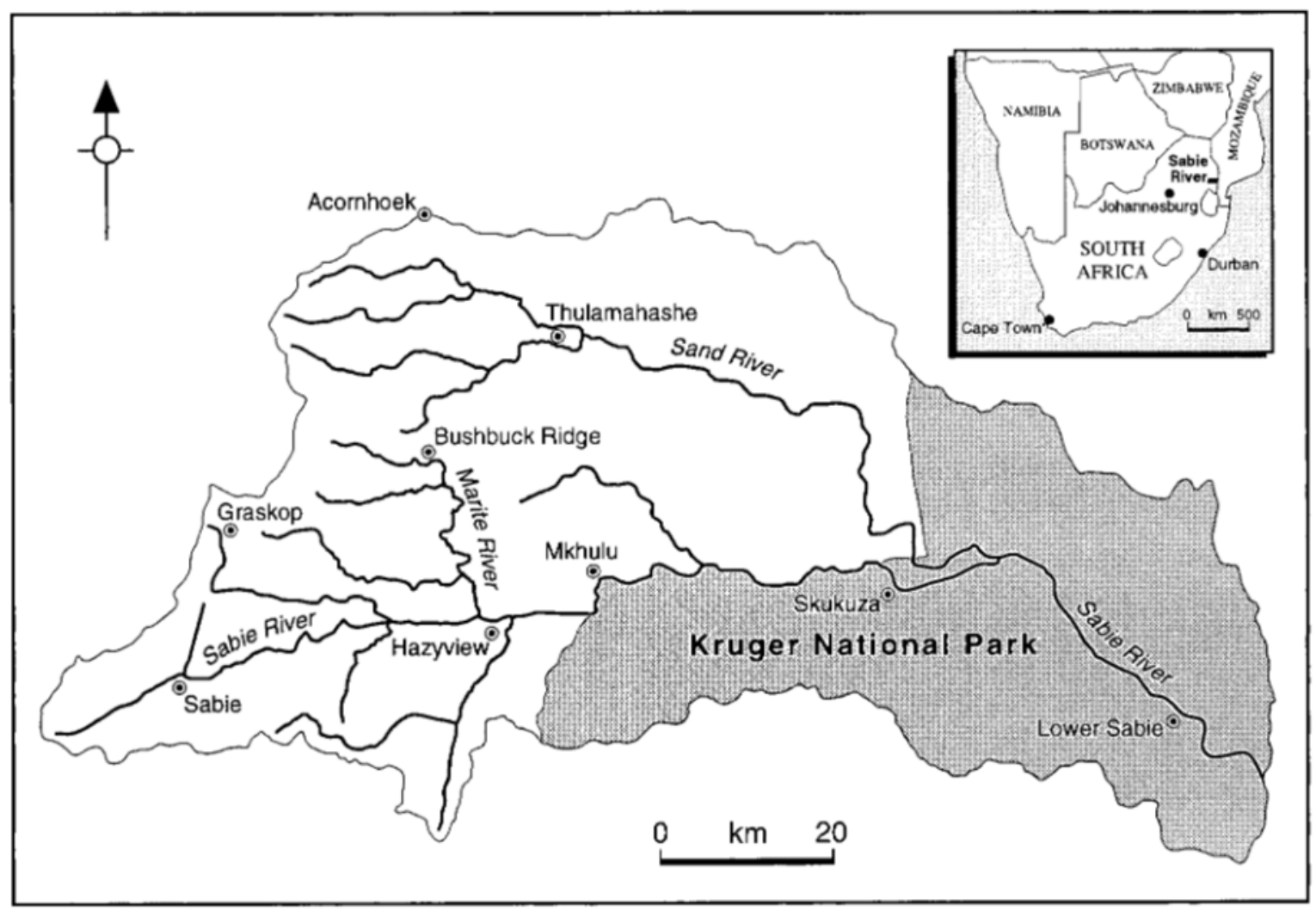

Figure 1. Location of the Sabie River, Mpumalanga Province, South Africa

from regional to microhabitat (Brussock et al. 1985; Rosgen 1985, 1994; Frissell et al. 1986; Cupp 1989; van Niekerk et al. 1995; Rowntree and Wadeson 1996). Such an approach has developed from the knowledge that different processes influence geomorphic form, depending on the scale of feature being investigated. Wolman and Gerson (1978) recognized that the development of landscapes, catchments, and rivers, although linked, are controlled by different sets of processes. Similarly, rates of change vary depending on the spatial scale being considered. A hierarchical classification places these factors in context and defines the constraints under which a system can develop.

The majority of the hierarchies are structured from the catchment scale downward on the basis that it is the catchment variables that control the dynamics and, hence, the morphology of the river (Van Deusen 1954). The spatially nested river system hierarchy developed by Frissell et al. (1986), in which a system at one level forms the environment for the subsystems below it, has gained wide acceptance within the research community. Classification of entire river systems using this top-down approach has proved difficult on some rivers. This is because the interaction of many catchment variables (particularly, local geology) as part of a complex interlinked system produces a variety of morphological features that make each river system a unique entity (Heritage et al. 1999).

This effect is most apparent when an empirical hierarchy such as that developed by Frissell et al. (1986) is imposed on a river where the catchment characteristics are very different from those of the rivers on which the classification was developed. In these situations, the structural rigidity of the empirical hierarchy, imposed by the controls defined by the study catchment on which the hierarchy was developed, prohibits the hierarchy's meaningful use on rivers of a different nature. For example, a top-down hierarchy developed on an alluviated river, where tributary sediment inputs dominate the catchment control factors, could not then be applied to structure a bedrock-influenced channel that is affected by different catchment controls such as the underlying geology.

Mosley (1987) notes, however, that it may prove more useful to classify rivers according to their 
Table 1. Character and Location of the Morphological Units Found on the Sabie River in the Kruger National Park, South Africa

\begin{tabular}{lcc}
\hline \multirow{2}{*}{ Sediment influence } & \multicolumn{2}{c}{ Location in the channel } \\
\cline { 2 - 3 } Bedrock-influenced channel & Macrochannel & Active channel \\
& $\begin{array}{c}\text { Pavement, bedrock core bar, } \\
\text { bedrock backwater, } \\
\text { erosional bench, } \\
\text { bedrock distributary } \\
\text { Tlluvial-influenced channel }\end{array}$ & $\begin{array}{c}\text { Isolated rock, rapid, bedrock pool, } \\
\text { bedrock distributary }\end{array}$ \\
& $\begin{array}{c}\text { point bar, alluvial } \\
\text { backwater, island, } \\
\text { macrochannel bank, } \\
\text { alluvial distributary, } \\
\text { mixed distributary }\end{array}$ & $\begin{array}{c}\text { Lateral bar, point bar, lee bar, } \\
\text { alluvial pool, alluvial } \\
\text { distributary, mixed distributary, } \\
\text { riffle-pool, braid bar, } \\
\text { chute-channel, boulder bed, } \\
\text { armored area, levee }\end{array}$ \\
\hline
\end{tabular}

Note. Based on features identifiable on $1: 10,000$ aerial photograph interpretation. Smaller morphological units are present within the channel but cannot be reliably mapped from the $1: 10,000$ aerial photographs available to this study.

component parts, in other words, to generate a bottom-up agglomerative hierarchical system. This has the advantage of not imposing any initial hierarchical structure on the system but relies on morphological associations to generate the hierarchy. The identification of small-scale morphological units also allows the river to be assessed on a biological basis since many of these units are also ecologically meaningful.

This study reports on an attempt to classify and zone a morphologically complex bedrock-influenced river channel, the Sabie River, South Africa, based on associations between component morphological units. Lengths of the river have been

Table 2. Description of Bedrock and Sedimentary Morphological Units Found on the Sabie River in Kruger National Park, South Africa

\begin{tabular}{|c|c|}
\hline Morphological unit & Description \\
\hline Macrochannel bank & Banks of the incised river within which all fluvial deposits are contained. \\
\hline Rapid & Steep bedrock sections, high-velocity concentrated flow. \\
\hline Erosional bench & $\begin{array}{l}\text { Subhorizontal terrace-like feature on bedrock representing a former } \\
\text { active-channel surface. }\end{array}$ \\
\hline Pool & $\begin{array}{l}\text { Reach of channel below the level of the average channel gradient line. } \\
\text { May be bedrock, upstream of a bedrock control; alluvial, upstream of } \\
\text { an accumulation of sediment or mixed, a bedrock feature presently } \\
\text { accumulating sediment. }\end{array}$ \\
\hline Riffle & $\begin{array}{l}\text { Accumulation of coarser sediment as a topographic high point as part of } \\
\text { an alluvial pool-riffle sequence. }\end{array}$ \\
\hline Isolated rock & $\begin{array}{l}\text { Outcrop of bedrock or boulder that has no significant impact on the } \\
\text { gradient of the water surface. }\end{array}$ \\
\hline Braid bar & $\begin{array}{l}\text { Accumulation of sediment in midchannel, causing the flow to diverge } \\
\text { over a scale that approximates to the channel width. }\end{array}$ \\
\hline Lateral bar & $\begin{array}{l}\text { Accumulation of sediment attached to the side of the channel, may } \\
\text { occur sequentially downstream as alternate bars. }\end{array}$ \\
\hline Point bar & Accumulation of sediment on the inside of a meander bend. \\
\hline Bedrock core bar & $\begin{array}{l}\text { Accumulation of finer sediment on top of bedrock in bedrock anasto- } \\
\text { mosing areas. }\end{array}$ \\
\hline Lee bar & Accumulation of sediment in the lee of flow obstructions. \\
\hline Backwater & $\begin{array}{l}\text { Stationary or near-stationary bodies of water in bedrock or alluvium or a } \\
\text { mixture of both, adjacent to the active channel. }\end{array}$ \\
\hline Chute channel & $\begin{array}{l}\text { High discharge distributary channel on the inside of point and } \\
\text { lateral bars. }\end{array}$ \\
\hline Boulder bed & Accumulation of locally derived material exceeding $.25 \mathrm{~m}$. \\
\hline Armored area & Accumulation of coarser sediments due to winnowing of finer material. \\
\hline Distributary & $\begin{array}{l}\text { Individual bedrock, alluvial, or mixed active channel in an alluvial } \\
\text { braided or anastomosing system. }\end{array}$ \\
\hline Island & Large midchannel sediment accumulation that is rarely inundated. \\
\hline Terrace & Relic floodplain or valley floor deposits above the present river level. \\
\hline
\end{tabular}

Note. From van Niekerk et al. 1995. 
Table 3. Morphological Composition of the Primary Channel Types Found on the Sabie River in Kruger National Park, South Africa

\begin{tabular}{lc}
\hline Channel type & Description \\
\hline Alluvial single-thread & Uniform single-channel river. Limited bedrock outcrops or braid \\
& bars associated with active channel. May be bedrock or alluvial. \\
Alluvial braided & Multichannel system with impermanent distributaries in alluvium. \\
& Channel convergence and divergence occur on the scale of \\
channel width. & Multichannel system of distributaries in bedrock and alluvium. \\
Mixed anastomosing & Multichannel system of permanent bedrock distributaries. Sedi- \\
Bedrock anastomosing & ment may accumulate on topographic highs. \\
Pool-rapid & System of shallow, faster, steeper bedrock-dominated rapids and \\
& associated upstream backwater pools.
\end{tabular}

Note. From van Niekerk et al. 1995. Intermediate channel types may occur that are transitional between the principal channel types.

mapped at the level of morphological unit, and these areas are split into $150-\mathrm{m}$ sublengths for characterization and quantification of their morphology. Cluster analysis is then used to determine associations between the morphological units, thereby zoning the river system into a series of channel types exhibiting similar geomorphological character. The strength of the cluster analysis associations was tested using discriminant analysis and were found to be robust.

The resultant geomorphological hierarchy and river zonation are flexible and include a large number of morphological units that are rarely encountered in temperate alluvial river systems. It would also be possible to extend the classification system further to include features seen on other river types. The classification approach may be applied to superimposed or antecedent rivers and also to those cut into alluvium where terraces and berms may be present. Its flexibility and wide coverage allow any river to be classified systematically. Similarly, as new research is conducted into other river types, the list of geomorphological units can be extended and incorporated into the overall river classification process.

Fluvial form is related to process, and many discriminating factors have been proposed in the classification of channel types, usually related to some measure of available energy such as stream power. Energy slope, sediment transport, and sediment yield measures are examined for the resultant morphological classification in an attempt to link channel process and form.

\section{Study Area}

The Sabie River, Mpumalanga Province, South Africa, was selected for this study to test the geomorphological characterization method detailed above. The Sabie River rises on the Great Escarpment and flows eastward for $210 \mathrm{~km}$ to its confluence with the Incomati River in Mozambique (fig. 1). It drains an area of $6252 \mathrm{~km}^{2}$ in South Africa and a total area of $7096 \mathrm{~km}^{2}$ and flows through the Kruger National Park for approximately $110 \mathrm{~km}$ of its length. Annual rainfall varies from $2000 \mathrm{~mm}$ in

Table 4. Channel-Type Composition of the 150-m Sublength Cluster Analysis (1-18) of the Sabie River in Kruger National Park, South Africa

\begin{tabular}{|c|c|c|c|c|c|c|c|c|c|c|c|c|c|c|c|c|c|c|}
\hline Channel type & 1 & 2 & 3 & 4 & 5 & 6 & 7 & 8 & 9 & 10 & 11 & 12 & 13 & 14 & 15 & 16 & 17 & 18 \\
\hline $\begin{array}{l}\text { Alluvial single- } \\
\text { thread }\end{array}$ & 4 & $\cdots$ & $\cdots$ & $\cdots$ & $\cdots$ & $\cdots$ & $\cdots$ & $\cdots$ & $\cdots$ & $\cdots$ & $\ldots$ & $\ldots$ & $\cdots$ & $\cdots$ & $\cdots$ & $\cdots$ & $\ldots$ & \\
\hline $\begin{array}{l}\text { Single-thread/ } \\
\text { braided }\end{array}$ & 1 & $\ldots$ & $\ldots$ & $\ldots$ & $\ldots$ & $\ldots$ & $\ldots$ & $\ldots$ & $\ldots$ & $\cdots$ & $\ldots$ & $\ldots$ & $\ldots$ & $\ldots$ & $\ldots$ & $\ldots$ & $\ldots$ & \\
\hline Alluvial braided & 29 & $\ldots$ & $\ldots$ & $\ldots$ & $\ldots$ & $\ldots$ & $\ldots$ & $\cdots$ & $\ldots$ & 1 & $\ldots$ & $\ldots$ & $\ldots$ & $\ldots$ & $\ldots$ & $\ldots$ & $\ldots$ & \\
\hline Braided/pool-rapid & 2 & $\ldots$ & $\ldots$ & $\ldots$ & $\ldots$ & $\ldots$ & $\ldots$ & $\ldots$ & $\ldots$ & 2 & 1 & $\ldots$ & $\ldots$ & $\ldots$ & $\ldots$ & $\ldots$ & $\ldots$ & $\cdot$ \\
\hline $\begin{array}{l}\text { Bedrock pool-rapid } \\
\text { Bedrock anasto- }\end{array}$ & 7 & 1 & 2 & 1 & $\ldots$ & $\ldots$ & $\ldots$ & $\ldots$ & $\ldots$ & 19 & 8 & $\ldots$ & 2 & $\ldots$ & $\ldots$ & $\ldots$ & 1 & \\
\hline $\begin{array}{l}\text { mosed/pool-rapid } \\
\text { Bedrock }\end{array}$ & $\ldots$ & 1 & $\ldots$ & $\ldots$ & $\ldots$ & $\ldots$ & $\ldots$ & $\ldots$ & $\ldots$ & 1 & $\ldots$ & $\ldots$ & $\ldots$ & $\ldots$ & 1 & $\ldots$ & $\ldots$ & \\
\hline anastomosing & 1 & $\ldots$ & $\ldots$ & 4 & 2 & 1 & 1 & $\ldots$ & 1 & 2 & $\ldots$ & 5 & $\ldots$ & 7 & $\ldots$ & 2 & 1 & 3 \\
\hline Mixed anastomosing & 1 & $\ldots$ & $\ldots$ & 3 & $\ldots$ & $\ldots$ & $\ldots$ & 1 & $\ldots$ & 2 & 9 & 1 & 6 & $\ldots$ & $\ldots$ & 4 & 1 & .. \\
\hline Total & 45 & 2 & 2 & 8 & 2 & 1 & 1 & 1 & 1 & 27 & 18 & 6 & 8 & 7 & 1 & 6 & 3 & 3 \\
\hline
\end{tabular}

Note. Bold type indicates dominant channel type for each cluster by frequency. 

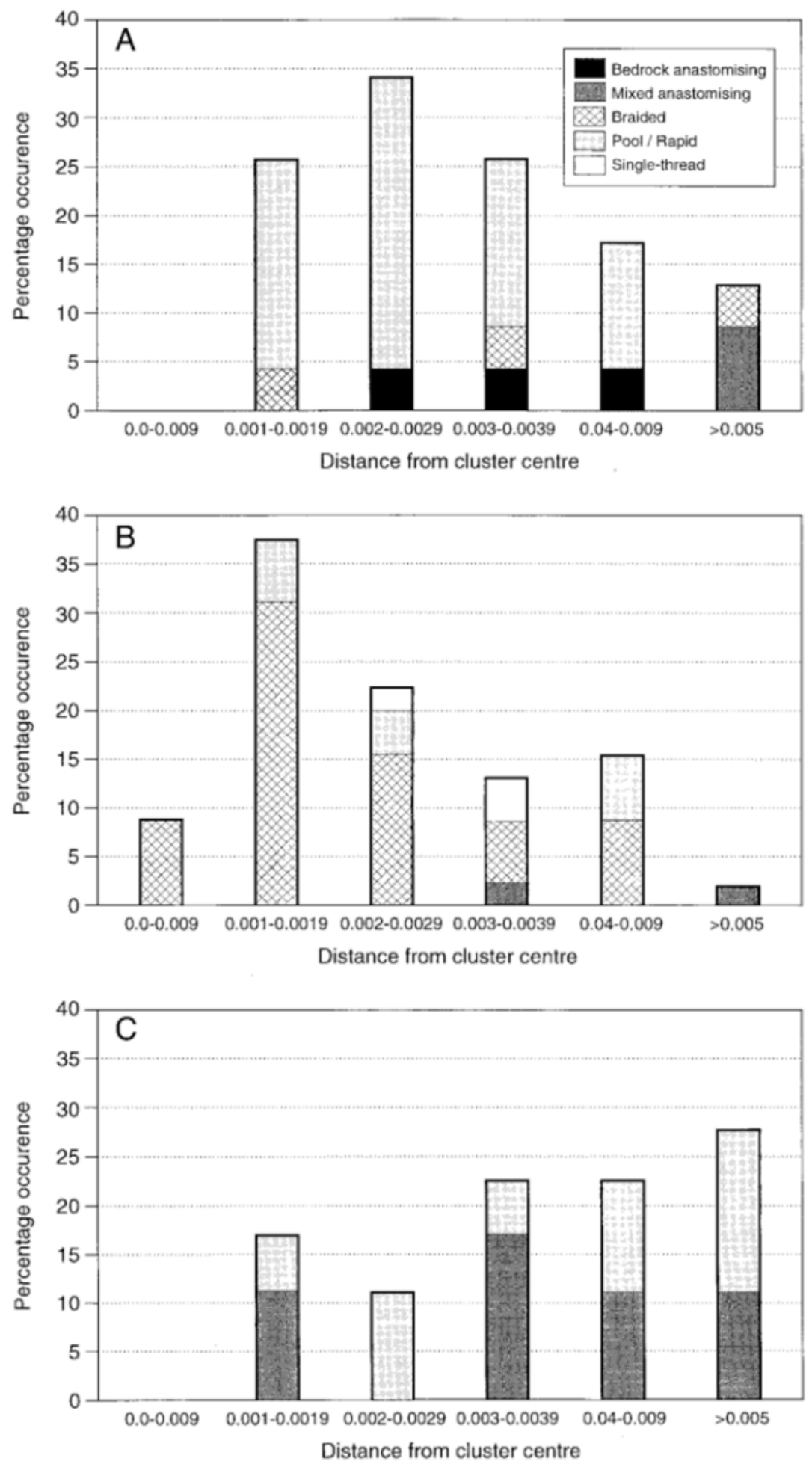

Figure 2. Channel-type association within the principal clusters identified for the Sabie River in Kruger National Park, South Africa. Association is measured as the distance between cluster centroids. 


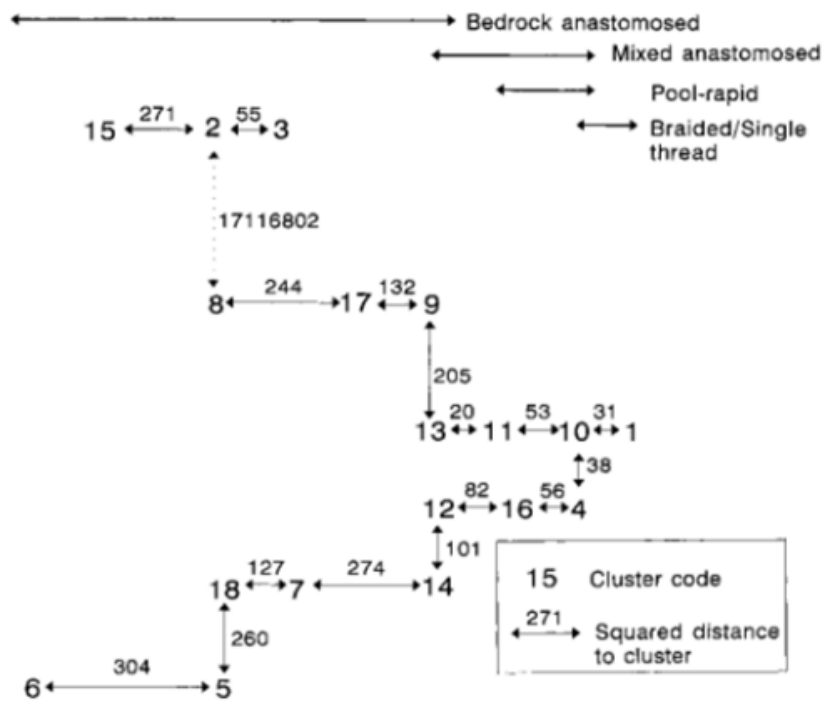

Figure 3. A channel-type continuum for the Sabie River in Kruger National Park, South Africa, as defined by the distance between cluster centroids.

the mountainous upstream portion of the catchment to $400 \mathrm{~mm}$ close to the Mozambique border. The flow regime of the Sabie River is characteristic of semiarid systems in which extremes of discharge occur with low winter base flows of $1-2 \mathrm{~m}^{3} \mathrm{~s}^{-1}$, occasional high summer flood flows in excess of $100 \mathrm{~m}^{3} \mathrm{~s}^{-1}$, and very rare major floods on the order of $1000-1500 \mathrm{~m}^{3} \mathrm{~s}^{-1}$. During nondrought years, several summer midrange flows on the order of 20-40 $\mathrm{m}^{3} \mathrm{~s}^{-1}$ occur. During drought periods, summer and winter base flows are reduced and summer high and intermediate flows are less frequent.

Examination of detailed cross-section profiles shows that the Sabie River consists of a macrochannel and one or more active channels (van Niekerk and Heritage 1993). The macrochannel extends across the width of the incised "valley" and contains the full extent of sedimentary deposits and riparian vegetation within the valley. Flow within the macrochannel is normally confined to smaller active channels. Extensive alluvial deposits occur in places; in other areas, bedrock features dominate. The active channels carry water throughout the year, and some seasonal channels become active during the higher summer flows. Sediment deposits occur within the active channels and along their margins, although bedrock frequently outcrops in the channel (Heritage and Moon 2000).

The interaction of bedrock and alluvium along the Sabie River has generated a varied assemblage of morphological units in the active and macro- channel (tables 1, 2). These are described in detail in Heritage and Moon (2000). Cluster analysis was used to investigate the similarity in geomorphological character of the mapped sublengths and to determine the morphological hierarchy. The cluster analysis data were derived from the geomorphological mapping of $25 \mathrm{~km}$ of the river in the Lowveld $15-\mathrm{km}$ bedrock anastomosing, $6.5-\mathrm{km}$ pool-rapid, 8- $\mathrm{km}$ mixed anastomosing, $1-\mathrm{km}$ singlethread, and $4.5-\mathrm{km}$ braided). Aerial photographs of the Sabie in $1986\left(0.75 \mathrm{~m}^{2}\right.$ plates at $1: 10,000$ scale $)$ were digitized, mapping the aerial extent of features at the level of morphological unit (table 2). The 150m-long mapped sublengths were given a channel type based on an observational discrimination of broad channel-type characteristics defined by van Niekerk et al. (1995) and detailed in table 3.

\section{Morphological Unit-Based Statistical Analysis}

A $k$-means cluster analysis was conducted on the data followed by a discriminant analysis to ascertain the reliability of the clustering. The analysis was restricted to 18 clusters, all of which proved to be robust following the discriminant analysis. The results of the cluster analysis show that a certain channel type (table 4) dominates each cluster. Three large clusters emerge. Cluster 1 is composed principally of alluvial channel types, particularly braided segments; it also contains the only alluvial single-thread segments mapped on the Sabie River. Several pool-rapid segments also fall into this cluster; however, most of these are located toward its periphery, having cluster distances farthest from the centroid (fig. 2A). Cluster 10 is dominated by pool-rapid channel-type segments, together with a few peripheral anastomosed channels at the periphery of the cluster (fig. 2B). Cluster 11 forms the third largest cluster and contains both pool-rapid and mixed anastomosed channel-type segments, indicating a similarity between the two (fig. 2C). Clusters 4,13 , and 16 contain a further 22 segments, the majority of which are mixed anastomosed. Clusters 12, 14, 17, and 18 are dominated by bedrock anastomosed channels. The remaining clusters contain only one or two members that fail to link with any of the other segments based on the measured morphological criteria.

It is clear from the cluster arrangement that morphological similarities exist between certain channel types, for instance, the mixture of braided, single-thread, and pool-rapid channel types in cluster 1 . The distance between cluster centroids was used to construct a continuum of channel types based on the degree of morphological similarity (fig. 
Table 5. Morphologic Variables Potentially Influential in Determining Cluster Groupings for the Sabie River in Kruger National Park, South Africa

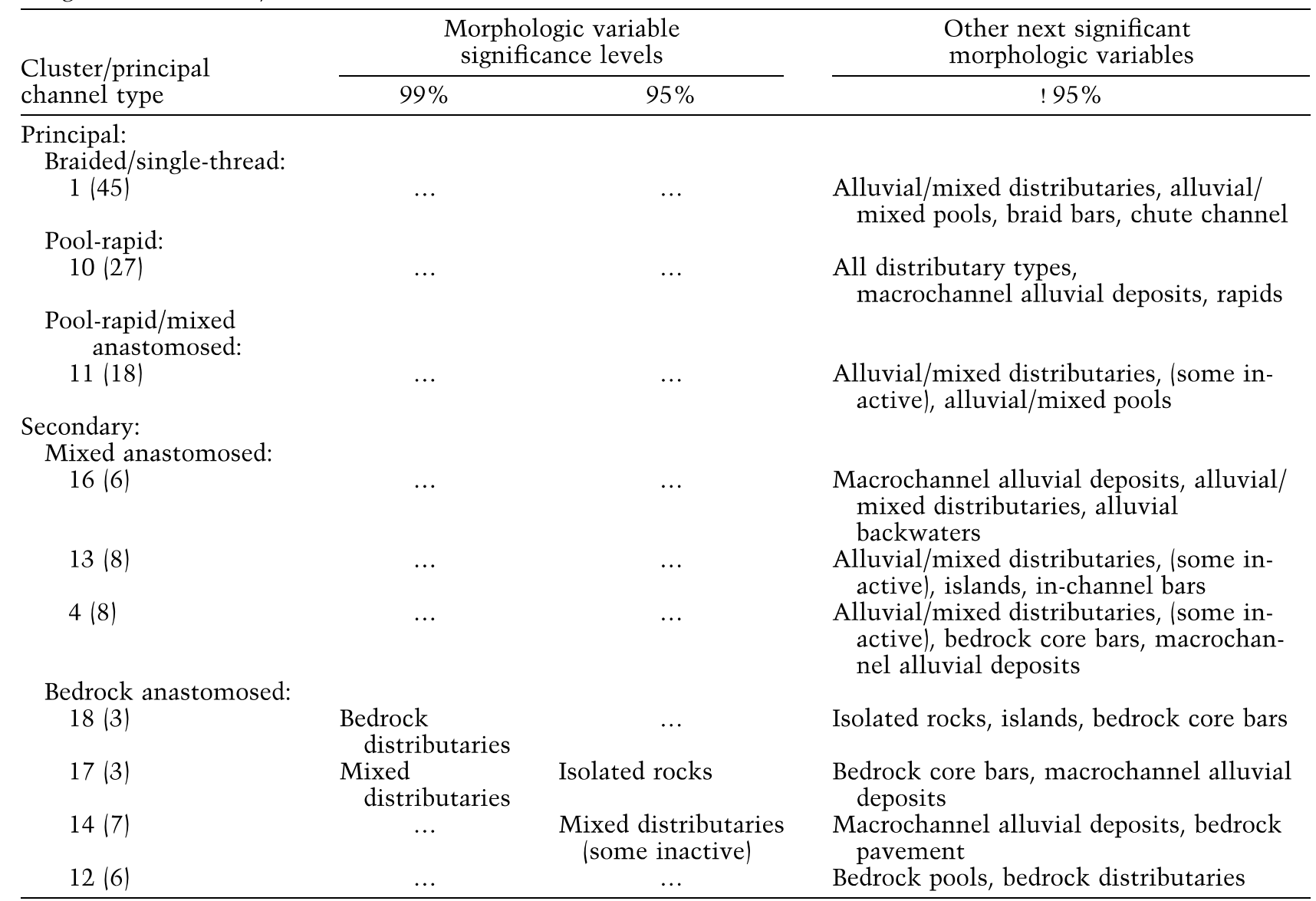

Note. Numbers in parentheses indicate cluster population.

3). It would appear from the data that a channeltype sequence ranging between bedrock anastomosing, mixed anastomosing, pool-rapid, singlethread, and braided can be identified. Such a sequence reflects the buildup of alluvium on top of the bedrock floor of the macrochannel, with the bedrock anastomosing segments displaying a multiple-channel network as defined by weaker joint and fracture patterns. As sediment accumulates on the interfluves between the active bedrock distributaries, the system assumes a mixed anastomosed character. Progressive alluviation may fully sediment some of the distributaries leading to the channel, assuming a pool-rapid nature; further alluviation may deposit in-channel bars and reduce the influence of rapids tending toward a braided or alluvial single-thread channel. Ashley et al. (1988) also support such a continuum, from bedrock through alluvial channels.

Each cluster was investigated at the level of morphological unit to determine the features that may be influential in causing the subunits to be associated with a particular channel type. A significant positive or negative difference between the mean value for each morphological unit in each of the clusters with the whole-river mean value indicates the influence of a morphological feature in determining the sublength clusters. This difference may be normalized across the clusters using equation (1):

$$
\frac{\text { global mean - cluster mean }}{\text { cluster standard deviation }} \text {. }
$$

Values greater than 2.58 indicate that the variable is significant at the $99 \%$ confidence level, and those greater than 1.96 indicate a significant variable at the $95 \%$ confidence level; the values may be positive or negative. Table 5 lists the most significant morphological units determining the principal clusters from the analysis. It is clear from the analysis that relationships may be identified between certain morphological units and channel types, although the level of statistical significance is often below the 95\% confidence level. As such, certain morphological units may be used to characterize 


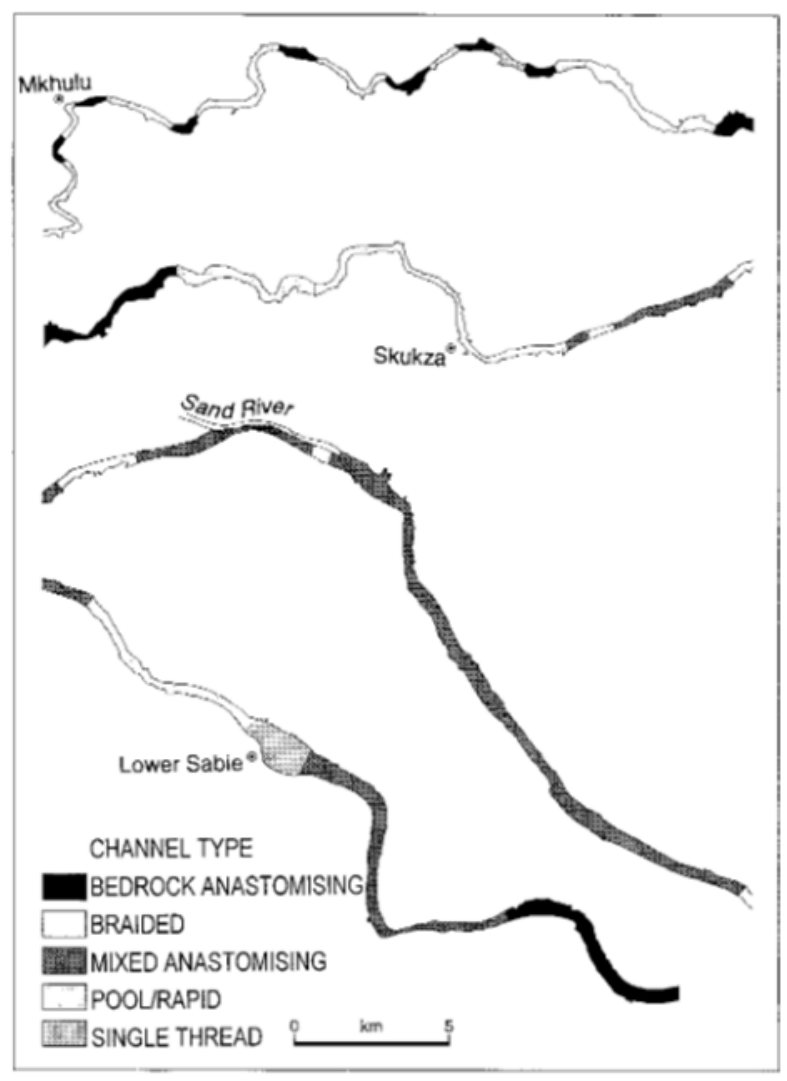

Figure 4. Channel-type zonation of the Sabie River in Kruger National Park, South Africa (after van Niekerk and Heritage 1993).

certain channel types on the Sabie River. In the case of bedrock anastomosed channels, bedrock distributaries are highly characteristic, followed by the presence of bedrock core bars and other macrochannel alluvial deposits (macrochannel lateral bars, macrochannel point bars, etc.). Mixed anastomosed channels are characterized by alluvial and mixed distributary channels, macrochannel alluvial deposits, and in-channel bars. Pool-rapid channels still display prominent distributary channels, particularly where transitional with mixed anastomosed channel types (cluster 11, table 5) and inchannel rapids become significant. Alluvial braided and single-thread channels are characterized by alluvial and some mixed distributaries, in-channel bars, and chute channels.

This series of characteristic deposits reflects the previously identified continuum of channel types as defined by the degree of alluviation. Bedrock anastomosed channels display a variety of bedrock features. Mixed anastomosed areas exhibit partially alluviated mixed distributaries and interfluve de- posits. Pool-rapid areas are characterized by prominent macrochannel alluvial bars but still retain active in-channel rapids. Braided channels are dominated by in-channel alluvial deposits and display only very occasional bedrock influence in the form of mixed distributaries. Single-thread channels, similarly, are characterized by an absence of bedrock features. All of this evidence again supports the idea of a continuum of channel types with successively more alluvial features dominating as sediment accumulates.

\section{Process Linkage and the Continuum of Channel Types on the Sabie River}

The existence of a continuum of channel types within the Sabie River that can be related to the degree of alluviation within the macrochannel may be related to the flow and sediment transport processes operating over time. Zonation of the Sabie River in the Kruger National Park based on the fivefold principal channel-type agglomerative classification reveals 40 individual channel-type segments (fig. 4). Each channel-type segment was investigated to quantify the following process-related hydraulic, sediment-delivery, and sediment-transport parameters:

Low Flow Slope. Measured water-surface slope, using the centerline distance downstream, at flows varying between 1 and $3 \mathrm{~m}^{3} \mathrm{~s}^{-1}$.

Flood Flow Slope. Measured 1800-2200 $\mathrm{m}^{3} \mathrm{~s}^{-1}$ flood-strandline slopes, using the centerline distance downstream and regional slope data extracted from topographic maps.

Annual Potential Sediment Transport Rate. Predicted maximum annual sediment transport using the Ackers and White $(1973,1993)$ equations as described in Birkhead et al. (2000).

Mean Annual Runoff. Average annual runoff for each channel segment based on the ACRU /Schulze 2000) catchment sediment model as calculated by Birkhead et al. (2000)

Annual Sediment Delivery. Calibrated average annual sediment delivery to each channel segment based on the Agricultural Catchments Research Unit (ACRU) hydrologic model (Schulze 2000) catchment sediment model as calculated by Birkhead et al. (2000).

Calibrated Energy Slope. Energy slope required to transport delivered sediment to each channeltype segment as calculated by Birkhead et al. (2000).

Annual Average Sediment Storage. Volumetric average sediment accumulation within each channeltype segment as calculated by Birkhead et al. (2000).

The ACRU model was used to derive the flow 
Table 6. Summary Hydrodynamic Characteristics of Channel-Type Segments of the Sabie River in Kruger National Park, South Africa

\begin{tabular}{|c|c|c|c|c|c|c|c|c|c|}
\hline & $\begin{array}{l}\text { Regional } \\
\text { slope }\end{array}$ & $\begin{array}{l}\text { Low-flow } \\
\text { slope } \\
\left(\mathrm{a}^{\mathrm{a}} 1 \mathrm{~m}^{3} \mathrm{~s}^{-1}\right)\end{array}$ & $\begin{array}{l}\text { Calibrated } \\
\text { energy } \\
\text { slope }\end{array}$ & $\begin{array}{l}\text { Mean } \\
\text { annual } \\
\text { sediment } \\
\text { yield }\end{array}$ & $\begin{array}{l}\text { Mean } \\
\text { annual } \\
\text { runoff } \\
\text { (MAR) }\end{array}$ & $\begin{array}{c}\text { Mean } \\
\text { annual } \\
\text { sediment } \\
\text { transport } \\
\text { (MAS) }\end{array}$ & $\begin{array}{l}\text { MAS/ } \\
\text { MAR }\end{array}$ & $\begin{array}{l}\text { Yield/ } \\
\text { MAS }\end{array}$ & Storage \\
\hline \multicolumn{10}{|l|}{$\begin{array}{r}\text { Bedrock } \\
\text { anas }\end{array}$} \\
\hline Mean & .00351 & .00625 & .00572 & 25.5 & 468 & 308 & .77 & .08 & .02 \\
\hline Min & .00233 & .00140 & .00314 & 4.7 & 365 & 176 & .58 & .01 & .00 \\
\hline Max & .00571 & .01246 & .00644 & 89.4 & 810 & 785 & .97 & .28 & .07 \\
\hline Stdev & .00101 & .00358 & .00103 & 35.9 & 192 & 190 & .16 & .11 & .02 \\
\hline Median & .00342 & .00473 & .00609 & 12.6 & 390 & 233 & .82 & .04 & .01 \\
\hline \multicolumn{10}{|l|}{ Braided: } \\
\hline Mean & .00255 & .00050 & .00130 & 37.5 & 355 & 321 & .57 & .23 & .14 \\
\hline Min & .00160 & .00003 & .00115 & 4.7 & 340 & 153 & .45 & .03 & .00 \\
\hline Max & .00364 & .00190 & .00138 & 152.7 & 400 & 784 & .83 & 1.00 & .44 \\
\hline Stdev & .00059 & .00047 & .00008 & 56.7 & 23 & 218 & .13 & .38 & .14 \\
\hline Median & .00233 & .00034 & .00132 & 16.9 & 345 & 203 & .54 & .08 & .08 \\
\hline \multicolumn{10}{|l|}{$\begin{array}{l}\text { Mixed } \\
\quad \text { anasto }\end{array}$} \\
\hline Mean & .00240 & .00352 & .00291 & 90.9 & 642 & 611 & .93 & .12 & .38 \\
\hline Min & .00200 & .00173 & .00261 & 1.5 & 430 & 353 & .80 & .00 & .00 \\
\hline Max & .00284 & .00640 & .00331 & 435.9 & 800 & 785 & 1.02 & .56 & 1.01 \\
\hline Stdev & .00034 & .00178 & .00036 & 192.9 & 189 & 235 & .11 & .24 & .42 \\
\hline Median & .00225 & .00352 & .00269 & 2.6 & 770 & 778 & .97 & .01 & .29 \\
\hline \multicolumn{10}{|l|}{ Pool-rapid: } \\
\hline Mean & .00270 & .00096 & .00202 & 6.4 & 451 & 298 & .72 & .02 & .12 \\
\hline Min & .00178 & .00003 & .00149 & 2.1 & 340 & 172 & .51 & .00 & .00 \\
\hline $\operatorname{Max}$ & .00394 & .00301 & .00217 & 12.0 & 800 & 782 & .98 & .04 & .52 \\
\hline Stdev & .00072 & .00075 & .00018 & 3.6 & 174 & 162 & .18 & .01 & .13 \\
\hline Median & .00233 & .00092 & .00210 & 5.0 & 393 & 232 & .71 & .02 & .10 \\
\hline
\end{tabular}

and sediment data as it generated an extended record of the flow and sediment delivery conditions within the catchment for each of the 40 channeltype segments. This model has been shown to produce good results for similar semiarid catchments in southern Africa (Schulze et al. 1998; Schulze 2000). A further validation occurred with the flow calibration against recent local gauged daily flows (Birkhead et al. 2000).

The overall statistics for each parameter are summarized in table 6. A plot of the high and low flow slopes for each of the channel-type segments (fig. 5) reveals an indistinct trend of increasing low and high flow slope from braided to single-thread to mixed anastomosed to pool-rapid to bedrock anastomosing.

Such a trend in the flow-energy slope may be viewed as a reflection in the overall energy available to the system; bedrock anastomosed and poolrapid channels have the highest available energy and display relatively few sedimentary features. Mixed anastomosed channels show a reduced level of available energy, and this is reflected in an increased alluvial influence. Finally, the braided and single-thread channels have the lowest available energy and the greatest degree of alluviation in relation to the other bedrock-influenced channel types. This is partially reflected in the average annual storage volumes, with mixed anastomosed channel types displaying the highest accumulation rates followed by braided and pool-rapid channels. Bedrock anastomosing channel-type segments are accumulating sediment at the lowest rates (fig. 6A). The sediment delivery-sediment transport ratio as defined by the ACRU modeling results along the Sabie River provides another useful index for possible alluviation (fig. $6 B$ ). A value greater than unity indicates more sediment coming into the system than can be transported; this would favor sediment accumulation. The plot reveals the highest values for the braided channel-type segment followed by mixed anastomosing channels and finally bedrock anastomosing and pool-rapid channels, indicating a trend toward greater transport efficiency and reduced sediment accumulation.

\section{Discussion}

The results of an objective cluster analysis to determine the geomorphic character of a bedrock- 


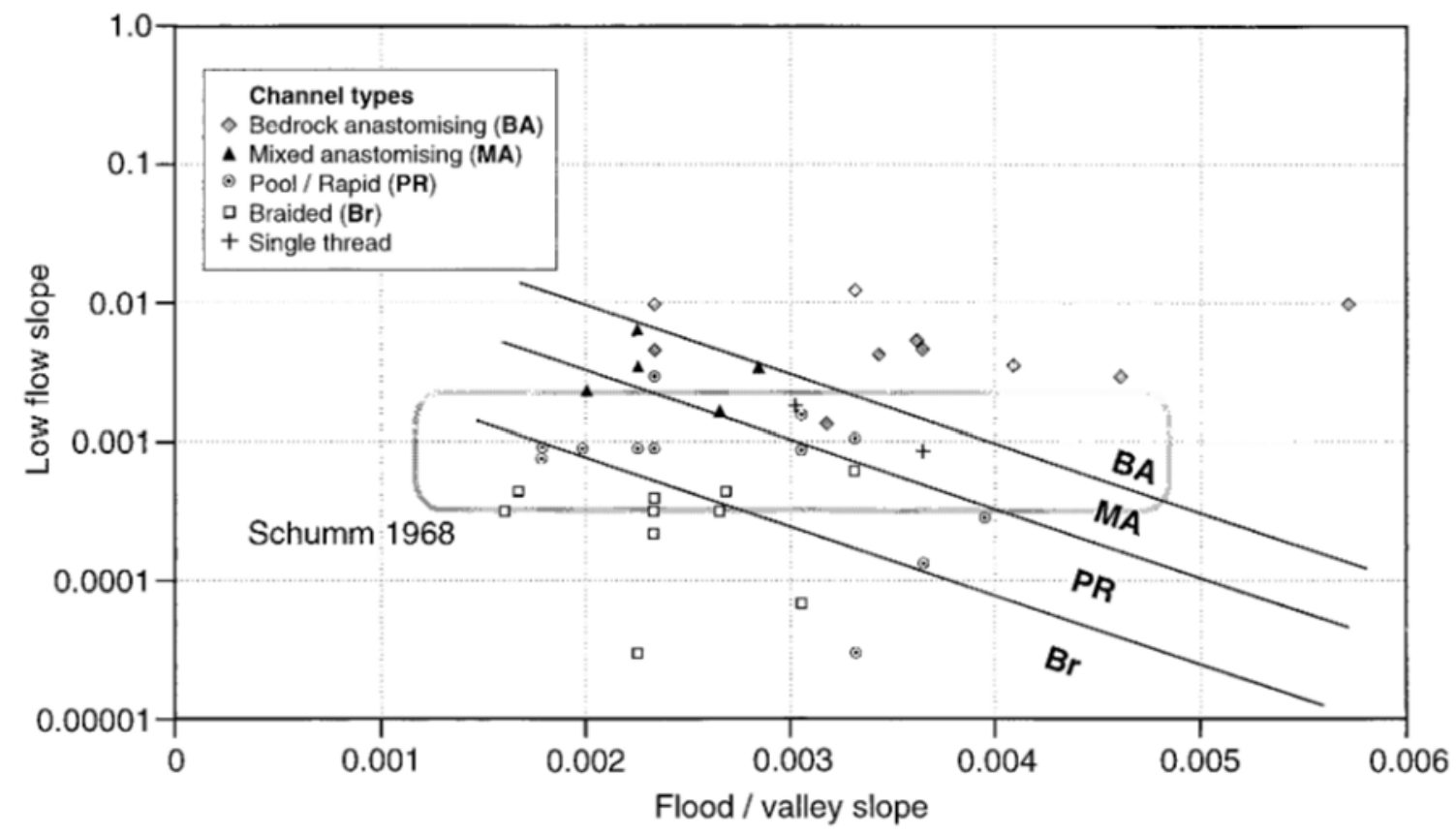

Figure 5. Slope characteristics of the channel-type segments of the Sabie River in Kruger National Park, South Africa. (The data of Schumm 1968 is also represented by the bounded area for comparison.)

influenced river system have been presented. Three significant large clusters were found that may be described as braided, pool-rapid, and mixed anastomosed, according to the terminology of van Niekerk et al. (1995); a further set of three similar sec- ondary clusters can be described as bedrock anastomosed. In all of these channel types, the influence of bedrock can be seen with its effect diminishing as alluvium accumulates.

It is clear from the character of the clusters that
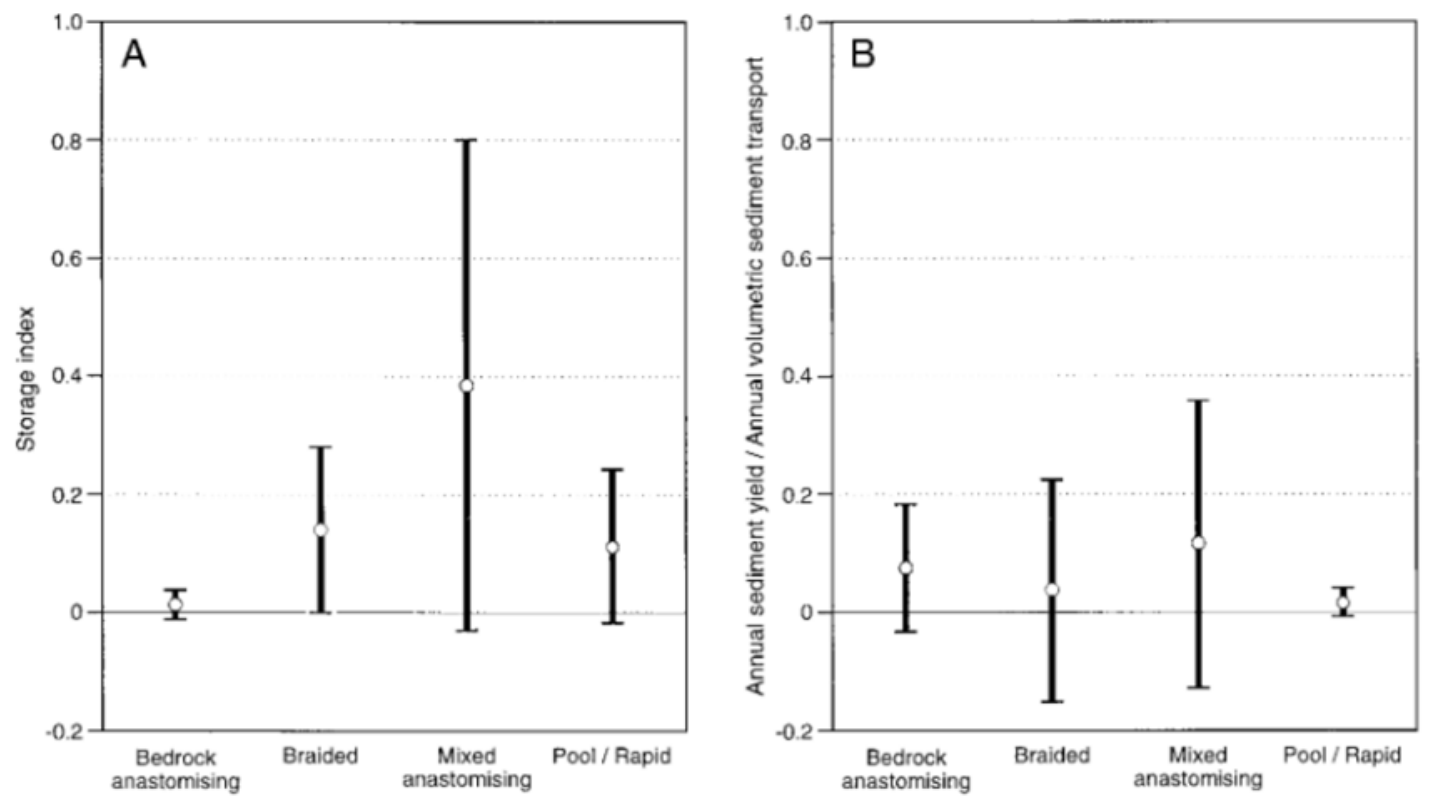

Figure 6. Process variable characterization of channel-type segments of the Sabie River in Kruger National Park 


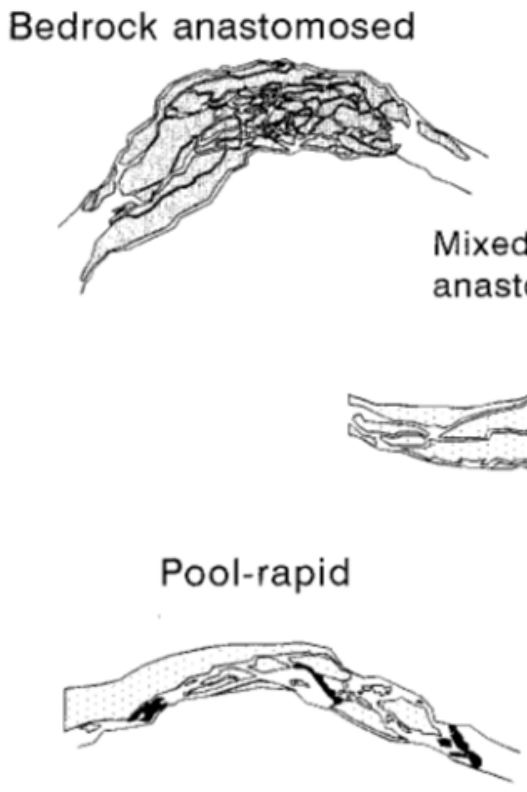

\section{Braided}

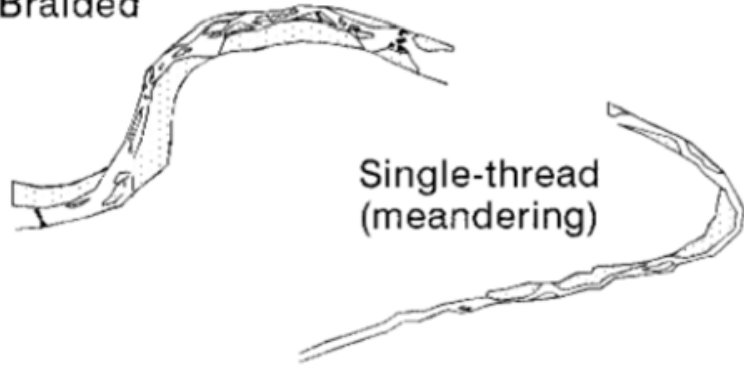

(Single-thread Straight)

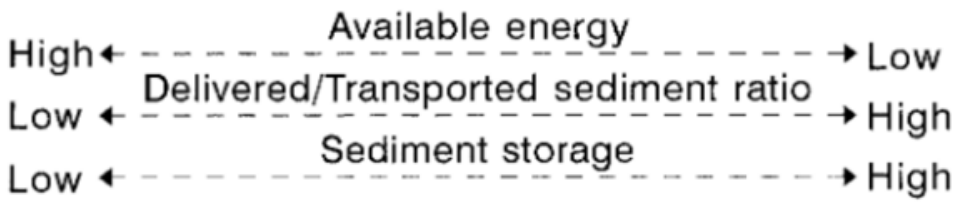

Figure 7. A revised continuum of channel types for bedrock-influenced channels based on available energy and channel pattern for the Sabie River in Kruger National Park, South Africa.

emerged that a continuum of channel types exists on the river, ranging from bedrock-dominated multi- and single-thread anastomosed and poolrapid channels to alluvial-dominated multi- and single-thread braided and single-thread channels. This continuum extends beyond the straightmeandering-braided classification of Leopold and Wolman (1957), extending to channel patterns and associated energy levels above those recorded for these alluvial channels.

Analysis of the distances between cluster centroids adds support to the concept of a continuum of channel types with bedrock-influenced channels clustering on one side of the continuum and alluvial on the other. Such a pattern has been suggested for other bedrock-influenced channels by Ashley et al. (1988). This pattern is further supported by an investigation of the principal morphological units that characterize each cluster. Bedrock channel types display a variety of bedrock morphological units and no alluvial deposits; there is then a series of transitional channel types characterized by macrochannel and active-channel alluvial units until all bedrock influence is lost in alluvial singlethread and braided channel types.

Leopold and Wolman (1957) argued that channel pattern is the result of the interaction of a set of continuous process variables; this was investigated for the bedrock-influenced Sabie River. Measures of the available energy within the channel types and the ratio of delivered to transported sediment also reveal that each channel type along the continuum may be characterized by a certain broad range of process variables. At the one end of the continuum, bedrock-influenced channels have very high levels of available energy and are efficient at transporting delivered sediment. In contrast, the alluvial channels display much reduced levels of 
available energy and are less efficient at transporting delivered sediment.

The pattern of increasing channel energy and the reduced ratio of sediment delivery to potential transport capacity links directly to increasing bedrock influence (fig. 7), and it is suggested that the bedrock-influenced channel types lie beyond the limits implied by other alluvial channel classification systems. On a simple energy ranking, the mixed anastomosed and mixed pool-rapid channel types would have generally higher available energy levels than alluvial braided, meandering, and straight channels. Still higher energy levels are available to bedrock anastomosed and bedrock pool-rapid channels.

The proposed continuum (fig. 6) agrees with the suggestions of Ashley et al. (1988) and reflects the quantitative findings of many researchers, including Leopold and Wolman (1957), Schumm (1985), and Knighton and Nanson (1993), concerning the position of the alluvial channel types. However, the position of the mixed anastomosed channel type is interesting; field measurements of available energy suggest that this channel type sits at the top end or above the energy levels of other more alluvial channel types, particularly alluvial anastomosed channels (Schumm 1985).
The mixed anastomosing channel type on the Sabie River is visually similar to the type 4 alluvial anastomosed system defined by Nanson and Knighton (1996); both are characterized by sanddominated parallel ridges. However, the Sabie mixed anastomosed system is formed as a result of deposition of sands, fine gravels, and cohesive silts on top of a high-energy bedrock anastomosed channel network. As such, the energy levels associated with this type of system are higher than those recorded for the type 4 alluvial anastomosed system defined by Nanson and Knighton. It is suggested that the Sabie mixed anastomosed system falls outside of the classification proposed by them, possibly forming a further division in their six-type division of anabranching channels (fig. 7).

\section{A C K N O W LED G M E N T S}

We thank the Water Research Commission of South Africa for financing the research. The National Parks Board of South Africa provided logistical support. G. Dobrzynski kindly assisted with the maps and diagrams. The reviewers are thanked for their constructive comments.

\section{RE F E R E N C E S C I T E D}

Ackers, P.W., and White, R.W. 1973. Sediment transport: new approach and analysis. J. Hydraul. Div. ASCE 99: 2041-2060.

-1993. Sediment transport in open channels: Ackers and White update. Proc. Inst. Civil Eng. Water Marit. Energy Tech. Note 619. 101:247-249.

Ashley, G. M.; Renwick, W. H.; and Haag, G. H. 1988. Channel form and process in bedrock and alluvial reaches of the Raritan River, New Jersey. Geology 16: 436-439.

Birkhead, A. L.; Heritage, G. L.; James, C. S.; Rogers, K. H.; and van Niekerk, A. W. 2000. Geomorphological change models for the Sabie River, Kruger National Park. Water Res. Comm. Rep. 782/1/00. Pretoria, Water Research Commission.

Brussock, P. P.; Brown, A. V.; and Dixon, J. C. 1985. Channel form and stream ecosystem models. Water Resour. Bull. 21:859-866.

Church, M. 1992. Channel morphology and typology. In Calow, P., and Petts, G. E., eds. The rivers handbook (Vol. 1). Oxford, Blackwell Scientific, p. 126-143.

Cupp, C. E. 1989. Identifying spatial variability of stream characteristics through classification. Unpub. M.S. thesis, University of Washington, Seattle.

Frissell, C. A.; Liss, W. J.; Warren, C. E.; and Hurley, M. D. 1986. A hierarchical framework for stream habitat classification: viewing streams in a watershed context. Environ. Manag. 10:199-214.

Heritage, G. L., and Moon, B. P. 2000. The contemporary geomorphology of the Sabie River in the Kruger National Park. Koedoe 43:1-18.

Heritage, G. L.; van Niekerk, A.W.; and Moon, B. P. 1999. Geomorphology of the Sabie River, South Africa: an incised bedrock influenced channel. In Miller, A. J., and Gupta, A., eds. Varieties of fluvial form. Chichester, Wiley, p. 53-79.

Knighton, A. D., and Nanson, G. C. 1993. Anastomosis and the continuum of channel pattern. Earth Surf. Proc. Landf. 18:613-625.

Leopold, L. B., and Wolman, M. G. 1957. River channel patterns: braided, meandering and straight. U.S. Geol. Surv. Prof. Pap. 282B.

Mosley, M. P. 1987. The classification and characterisation of rivers. In Richards, K., ed. River channels environment and process. Oxford, Blackwell, p. 295-320.

Nanson, G. C., and Knighton, A. D. 1996. Anabranching rivers: their cause, character and classification. Earth Surf. Proc. Landf. 21:217-239.

Newson, M. D.; Clark, M. J.; Sear, D. A.; and Brookes, A. 1998. The geomorphological basis for classifying rivers. Aquat. Conserv. Mar. Freshw. Ecosyst. 8: 415-430. 
Rosgen, D. L. 1985. A stream classification in riparian ecosystems and their management reconciling conflicting uses. In U.S. For. Serv. Gen. Tech. Rep. M-120. Fort Collins, Colo., Rocky Mt. For. Range Exp. Stn. . 1994. A classification of natural rivers. Catena 22:169-199.

Rowntree, K. M., and Wadeson, R. A. 1996. Translating channel geomorphology into hydraulic habitat: application of the hydraulic biotope concept to an assessment of discharge related habitat changes. In LeClerc, M.; Capra, H.; Valentin, S.; Boudreault, A.; and Cote, Y., eds. The Proceedings of the 2d International Symposium on Hydraulic Habitats Ecohydraulique 2000. Quebec, IAHR, p. 342-351.

Schulze, R. E. 2000. Modelling hydrological responses to land use and climate change: a southern African perspective. Ambio 29:12-22.

Schulze, R. E.; Taylor, V.; and Pike, A. 1998. Sensitivity of hydrological responses to land use: results from a modelling study in the Pongola-Bivane catchment, South Africa. In Wheater, H., and Kirby, C., eds. Hy- drology in a changing environment (Vol. 2). Chichester, Wiley, p. 537-552.

Schumm, S. A. 1968. River adjustment to altered hydraulic regimen: Murrumbidgee River and palaeochannels, Australia. U.S. Geol. Surv. Prof. Pap., $598 \mathrm{p}$.

1985. Patterns of alluvial rivers. Annu. Rev. Earth Planet. Sci. 13:5-27.

Van Deusen, R. D. 1954. Maryland freshwater stream classification by watersheds. Chesapeake Biol. Lab. 106:1-30.

van Niekerk, A. W., and Heritage, G. L. 1993. Geomorphology of the Sabie River: overview and classification. Cent. Water Environ. Rep. 2/93. Johannesburg, University of the Witwatersrand 257-71, 100 p.

van Niekerk, A. W.; Heritage, G. L.; and Moon, B. P. 1995. River classification for management: the geomorphology of the Sabie River. S. Afr. Geog. J. 77:68-76.

Wolman, M. G., and Gerson, R. 1978. Relative scales of time and effectiveness of climate in watershed geomorphology. Earth Surf. Proc. Landf. 3:189-208. 